\title{
ERRATUM
}

Feras M. Hantash • Joy B. Redman • Kelsey Starn

Ben Anderson · Arlene Buller · Matthew J. McGinniss

Franklin Quan • Mei Peng • Weimin Sun

Charles M. Strom

\section{Novel and recurrent rearrangements in the CFTR gene: clinical and laboratory implications for cystic fibrosis screening}

Published online: 11 February 2006

(C) Springer-Verlag 2006

\section{Hum Gen (2006) DOl: 10.1007/s00439-005-0082-0}

The following three references that are cited in the Results section were omitted from the Reference list. The references are:

1. Monaghan KG, Feldman GL, Barbarotto GM, Manji S, Desai TK, Snow K (2000) Frequency and clinical significance of the S1235R mutation in the cystic fibrosis transmembrane conductance regulator gene: results from a collaborative study. Am J Med Genet 95:361-365
2. Castellani C, Gomez Lira M, Frulloni L, Delmarco A, Marzari M, Bonizzato A, Cavallini G, Pignatti P, Mastella G (2001) Analysis of the entire coding region of the cystic fibrosis transmembrane regulator gene in idiopathic pancreatitis. Hum Mutat 18:166

3. Reboul MP, Laharie D, Amouretti M, Lacombe D, Iron A (2003) Isolated idiopathic chronic pancreatitis associated with a compound heterozygosity for two mutations of the CFTR gene. Gastroenterol Clin Biol $27: 821-824$

We regret any inconvenience this might have caused.

The online version of the original article can be found at http:// dx.doi.org/10.1007/s00439-005-0082-0

F. M. Hantash $(\bowtie) \cdot$ J. B. Redman · K. Starn · B. Anderson

A. Buller · M. J. McGinniss · F. Quan · M. Peng · W. Sun

C. M. Strom

Department of Molecular Genetics, Quest Diagnostics Nichols

Institute, San Juan Capistranco, CA, USA

E-mail: feras.x.hantash@questdiagnostics.com

Tel.: + 1-949-7284286

Fax: + 1-949-7284874 